\title{
PENINGKATAN KUALITAS KESEHATAN PADA MANAJEMEN KONSTRUKSI SAAT PANDEMI MELALUI SOSIALISASI PEKERJA PROYEK
}

\author{
Anisza Ratnasari ${ }^{1}$, Marchelia Gupita Sari ${ }^{2}$, Imaniar Sofia Asharhani ${ }^{3}$, \\ ${ }^{1,2,3}$ Program Studi Arsitektur, Universitas Pradita
}

anisza.ratnasari@pradita.ac.id, marchelia.gupita@pradita.ac.id,imaniar.sofia@pradita.ac.id,

\begin{abstract}
Abstrak
Kondisi pandemi COVID-19 yang melanda Indonesia semakin mengkuatirkan, begitu juga yang dialami oleh Kabupaten Tangerang. Jumlah kasus terkonfirmasi semakin meningkat, padahal roda perekonomian tidak dapat berhenti total. Semua sektor ekonomi melakukan strategi agar dapat tetap produktif. PT.Summarecon Agung,Tbk., salah satu pengembang properti di Tangerang juga melakukan hal serupa. Selayaknya pengembang properti lainnya, Summarecon dalam pelaksanaan proyek konstruksi tetap mengkonsentrasikan pekerja pada lokasi proyek di saat yang sama. Kepadatan dan tingginya interaksi antar pekerja sangat potensial dalam penyebaran virus.

Gugus tugas penanganan Covid-19 PT.Summarecon Agung,Tbk dibentuk untuk mitigasi penyebaran virus pada proyek. Salah satu tugasnya adalah menyusun Protokol Kesehatan Pencegahan Penyebaran Covid-19. Protokol ini merupakan bagian dari kebijakan pemerintah untuk mewujudkan keselamatan konstruksi, khususnya kesehatan pekerja konstruksi. Protokol utama dalam pencegahan Covid-19, meliputi; pembentukan satuan tugas pencegahan Covid-19, identifikasi potensi bahaya Covid-19 di lapangan, penyediaan fasilitas kesehatan di lapangan dan pelaksanaan pencegahan Covid-19 di lapangan. Universitas Pradita bekerjasama dengan Gugus Tugas Pencegahan Covid-19 Summarecon mengawal pelaksanaan protokol kesehatan bagi para pekerja. Rangkaian kegiatan sosialisasi bertujuan untuk mengedukasi pekerja konstruksi sebagai upaya untuk meningkatkan kesadaran akan kesehatan pada manajemen konstruksi. Sasaran kegiatan ini adalah para pekerja konstruksi agar tetap produktif tanpa mengabaikan kesehatan dan keselamatan.
\end{abstract}

Kata Kunci: protokol kesehatan, pencegahan Covid-19, pekerja konstruksi

\section{PENDAHULUAN}

Penerapan pembatasan sosial berskala besar (PSBB) merupakan tindak lanjut dari Keputusan Menteri Kesehatan Republik Indonesia Nomor: HK01.07/Menkes/249/2020 yang dilakukan oleh Pemerintah Kota Tangerang dalam upaya memutus mata rantai dan percepatan penanganan penyebaran Covid-19. Summarecon Serpong sebagai salah satu developer properti di Tangerang dalam pelaksanaan proyek konstruksinya masih mengandalkan sistem padat karya dengan mengkonsentrasikan pekerja proyek dalam jumlah yang besar pada satu tempat di waktu yang sama. Kepadatan dan tingkat interaksi yang tinggi antar pekerja ini sangat potensial dalam penyebaran virus. Hal ini ternyata menjadi perhatian khusus bagi pemangku kepentingan, terbukti dengan dikeluarkannya Instruksi Menteri PUPR No C2 /1N/M/2020 tentang pencegahan penyebaran dan dampak Covid-19 dalam penyelenggaraan jasa konstruksi. Protokol 
pencegahan dalam penyelenggaraan jasa konstruksi ini tidak hanya diperuntukkan bagi penyedia jasa tetapi juga pengguna jasa, yang merupakan bagian dari keseluruhan kebijakan untuk mewujudkan keselamatan konstruksi termasuk keselamatan dan kesehatan kerja, keselamatan publik, dan keselamatan lingkungan pada setiap tahapan penyelenggaraan jasa konstruksi.

Adapun skema protokol Pencegahan Covid19 dalam penyelenggaraan jasa konstruksi, adalah sebagai berikut;
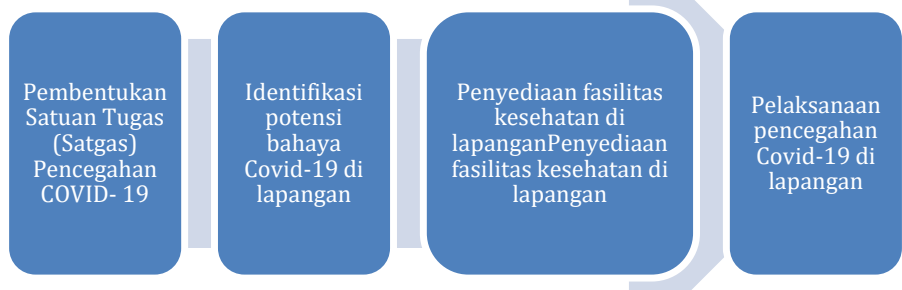

Gambar 1. Skema protokol pencegahan Covid-19 dalam penyelenggaraan jasa konstruksi

Pembentukan satuan tugas (satgas) pencegahan Covid-19 ini merupakan bagian dari Unit Keselamatan Konstruksi yang dibentuk oleh Pejabat Pembuat Komitmen (PPK) proyek tersebut. Anggota satgas Pencegahan Covid-19 berjumlah paling sedikit 5 (lima) orang yang terdiri atas ketua merangkap anggota dan anggota yang mewakili pengguna jasa dan penyedia jasa. Satgas Pencegahan Covid-19 memiliki tugas, tanggung jawab, dan kewenangan untuk melakukan: sosialisasi, pembelajaran/edukasi), promosi teknik, metode/pelaksanaan pencegahan Covid-19 di lapangan, berkoordinasi dengan Satgas Penanggulangan Covid-19 Kementerian PUPR melakukan identifikasi potensi bahaya Covid-19 di lapangan, pemeriksaan kesehatan terkait potensi terinfeksi Covid-19 kepada semua pekerja dan tamu proyek, pemantauan kondisi kesehatan pekerja dan pengendalian mobilisasi/demobilisasi pekerja, pemberian vitamin dan nutrisi tambahan guna peningkatan imunitas pekerja, pengadaan fasilitas kesehatan di lapangan, serta melaporkan kepada PPK dalam hal telah ditemukan pekerja yang positif dan/atau berstatus Pasien Dalam Pengawasan (PDP) dan merekomendasikan dilakukan penghentian kegiatan sementara.
Langkah kedua adalah identifikasi potensi bahaya Covid-19 di lapangan. Satgas pencegahan Covid-19 akan berkoordinasi dengan satgas penanggulangan covid-19 Kementerian PUPR untuk menentukan potensi risiko lokasi proyek terhadap pusat sebaran penyebaran Covid-19 di daerah yang bersangkutan, kesesuaian fasilitas kesehatan di lapangan dengan protokol penanganan Covid-19 yang dikeluarkan oleh pemerintah dan tindak lanjut terhadap penyelenggaraan jasa konstruksi. Penyelenggaraan jasa konstruksi dapat diberhentikan sementara akibat keadaaan kahar bila teridentifikasi; memiliki risiko tinggi akibat lokasi proyek berada di pusat sebaran, telah ditemukan pekerja yang positif dan/atau berstatus PDP, pimpinan kementerian/lembaga/instansi/kepaia daerah telah mengeluarkan peraturan untuk menghentikan kegiatan sementara akibat keadaan kahar.

Langkah ketiga adalan penyediaan fasilitas kesehatan di lapangan. Penyedia jasa wajib menyediakan ruang/klinik kesehatan di lapangan yang dilengkapi dengan sarana kesehatan yang memadai (tabung oksigen, pengukur suhu badan thermoscan, pengukur tekanan darah, obat-obatan, dan petugas medis), memiliki kerjasama operasional perlindungan kesehatan dan pencegahan Covid- 19 dengan rumah sakit terdekat untuk tindakan darurat, menyediakan fasilitas tambahan (pencuci tangan, air, sabun dan hand sanitizer, tisu, masker dikantor dan lapangan bagi seluruh pekerja dan tamu) serta wajib menyediakan vaksin, vitamin dan nutrisi tambahan guna peningkatan imunitas pekerja.

Tahap terakhir adalah pelaksanaan pencegahan Covid-19 di lapangan. Satgas pencegahan Covid-19 memasang poster/flyers baik digital maupun fisik tentang himbauan pencegahan Covid-19 untuk dipasang di tempat strategis di lokasi proyek. Selain dilakukan pengukuran suhu tubuh kepada seluruh pekerja, dan karyawan setiap pagi, siang, dan sore, harus juga disampaikan penjelasan, anjuran, kampanye, promosi cara pencegahan Covid-19 dalam setiap kegiatan penyuluhan K3 pagi hari (safety morning talk). Apabila di lapangan ditemukan pekerja kasus PDP Covid-19, pekerjaan harus diberhentikan sementara paling sedikit 14 hari kerja dan dilakukan evakuasi dan penyemprotan disinfektan pada seluruh tempat, fasilitas dan peralatan kerja. Penghentian sementara ini dilakukan hingga proses

$$
\text { Kesehatan }
$$


evakuasi dan penyemprotan disinfektan, serta pelaksanaan pemeriksaan kesehatan dan isolasi tenaga kerja yang pernah melakukan kontak fisik dengan tenaga kerja yang terpapar telah selesai.

Gugus tugas penanganan Covid-19 ini dibentuk untuk memutus mata rantai penyebaran virus pada proyek, baik bagi pengguna jasa dan maupun penyedia jasa. Salah satu tugasnya adalah menyusun Protokol Kesehatan Pencegahan Penyebaran Covid-19. Sebagai bentuk kepedulian Universitas Pradita terhadap Kejadian Luar Biasa (KLB) ini, para akademisi bekerjasama dengan Summarecon Serpong sebagai pengembang dan sekaligus pengguna jasa konstruksi dengan dukungan para kontraktor sebagai penyedia jasa konstruksi, dan aparat pemerintah setempat, bersama-sama melaksanakan sosialisasi protokol kesehatan sebagai upaya preventif menyebaran Covid-19 pada pekerja konstruksi di kawasan Symphonia, Tangerang.

Berdasarkan latar belakang diatas, dapat dilakukan analisis situasi pada proyek kawasan Symponia bahwa penerapan sistem padat karya masih memungkinkan untuk dilakukan dengan mengacu pada protokol kesehatan yang ketat. Berdasarkan data, sebaran asal para pekerja proyek ini $75 \%$ berasal dari luar Tangerang, dimana 58\% nya merupakan komuter aktif yang memiliki mobilitas tinggi pada tiap akhir pekan. Selain itu, diperoleh data bahwa tingkat penggunaan moda transportasi umum, berupa KRL, kereta, bus dan atau angkutan tinggi tergolong tingi, yaitu mencapai angka $89 \%$. Berdasarkan data tersebut, dapat dianalisis bahwa tingkat interaksi dengan khalayak sangat tinggi yang dimungkinkan meningkatkan prosentase tingkat paparan virus ini dari orang sekitar yang mereka jumpai di luar proyek. Hasil pre-test berupa wawancara terbuka (open ended interview) tentang pentingnya menjaga kesehatan pada masa pandemi dilakukan pada 27 dari 52 pekerja proyek bahwa sebagian berpendapat bahwa lingkungan lokasi pekerjaan 'kasar' dan 'kotor' tidak memungkinkan bagi mereka untuk mereka sering cuci tangan atau membersihkan diri. Selain itu, pada jenis tahapan proyek tertentu, misalnya, pada saat pengecoran, diperlukan konsentrasi pekerja yang cukup banyak pada suatu tempat tertentu, sehingga dimungkinkan tidak bisa melakukan pembatasan sosial atau menjaga jarak.

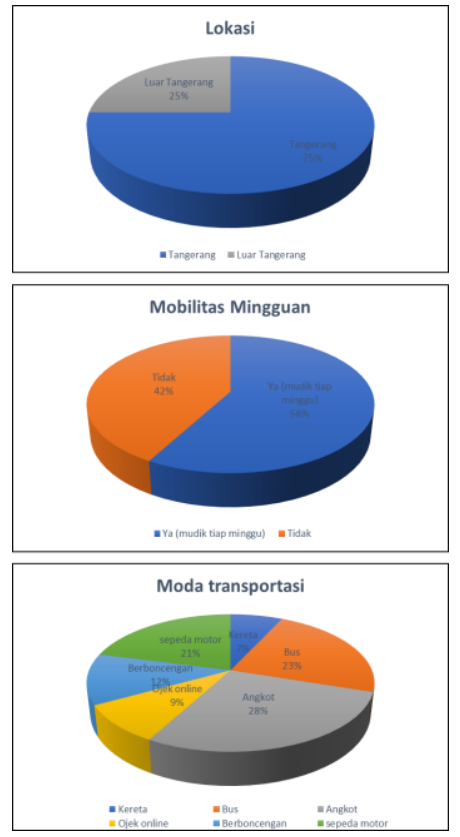

Gambar 2. Analisis situasi pekerja proyek, dilihat dari asal daerah domisili, mobilitas mingguan dan moda transportasi;

Dari analisis situasi diatas, dapat dirumuskan bahwa diperlukan pemahaman berupa edukasi tentang pentingnya melakukan protokol kesehatan bagi para pekerja proyek ini, dimana ini juga merupakan bagian penting yang tidak bisa diabaikan pada keseluruhan proses Protokol Pencegahan Covid-19 dalam Penyelenggaraan Jasa Konstruksi yang masih menerapkan sistem padat karya. Edukasi tersebut tidak hanya dilakukan secara oral, namun juga harus disosialisasikan dalam berbagai media, seperti poster, video atau praktik langsung supaya lebih efektif dan efisien..

Sasaran kegiatan ini adalah para pekerja proyek di lingkungan Summarecon Serpong, khususnya kawasan Symponia, Tangerang.Adapun tujuan khusus yang diharapkan dari kegiatan ini 
adalah untuk meningkatkan kualitas kesehatan pada manajemen konstruksi di masa pandemi pada pekerja proyek tersebut serta menjadi perpanjangan tangan dari pemerintah dan Gugus Tugas Covid-19 Summarecon Serpong untuk memutus mata rantai penyebaran Covid-19 pada pekerja proyek dengan lebih cepat dan tepat;

\section{METODE}

Metode pelaksanaan Pengabdian kepada Masyarakat (PkM) ini dilakukan dengan;

\section{a. Persiapan}

Pada tahap ini dilakukan koordinasi dengan Gugus Tugas Penanganan COVID-19 Summarecon Serpong serta melakukan analisis situasi para pekerja di proyek konstruksi. Hasil dari koordinasi ini didapatkan bahwa Tim PKM Universitas Pradita akan berkontribusi pada tahap ketiga dari skema kerja protokol pencegahan penyebaran Covid-19 dalam penyelenggaraan jasa konstruksi, yaitu tahap edukasi.

Pada fase ini akan dilakukan pre-test untuk mengukur tingkat pemahaman pekerja tentang pentingnya pelaksanaan protokol kesehatan di proyek. Mengacu pada tingkat kesibukan aktivitas pekerja, pre-test akandilakukan dalam bentuk open-ended interview (tanpa kuesioner) secara lisan dan informal. Hasil pre-test akan ditabulasi untuk nantinya dilakukan komparasi terhadap hasil akhir setelah para pekerja tersebut mendapatkan penyuluhan;

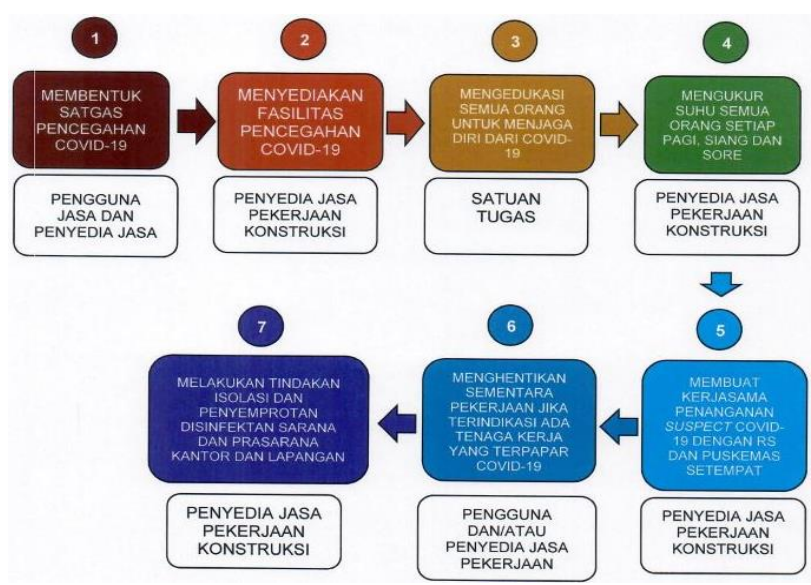

Gambar 3. Skema kerja protokol pencegahan penyebaran Covid-19 dalam penyelenggaraan jasa konstruksi

\section{b. Pelaksanaan}

Edukasi dilakukan tidak hanya pada para pekerja proyek, namun juga pengawas dan sub kontraktor yang menangani lokasi proyek. dilakukan dalam 2 (dua) metode, yaitu;

1) Media cetak, berupa spanduk/banner pada lokasi proyek;

2) Lisan; berupa penyuluhan oral di lokasi, dengan disertai;

- Demonstrasi protokol penerimaan;

- Demonstrasi protokol pelaksanaan;

\section{c. Evaluasi}

Evaluasi dilakukan untuk mengukur tingkat pengetahuan atau pemahaman pekerja proyek terhadap edukasi atau sosialisasi yang dilakukan. Evaluasi yang akan dilakukan dalam selang 4 (empat) minggu setelah evaluasi ini dilakukan dalam bentuk interview yang dilakukan secara lisan dan informal.

\section{HASIL DAN PEMBAHASAN}

\section{Persiapan}

Koordinasi dengan Gugus Tugas telah berlangsung dengan baik di lokasi proyek Kawasan Symphonia. Koordinasi membahas tatacara pretest dan sosialisasi yang efektif, berusaha sesuai dengan standar physical distancing yang digaungkan oleh pemerintah. Kondisi direksi kit proyek dinilai telah berusaha memenuhi protokol, yaitu dengan adanya ventilasi udara silang dan adanya physical distancing dalam pengaturan tempat duduk jika ada kegiatan pertemuan.

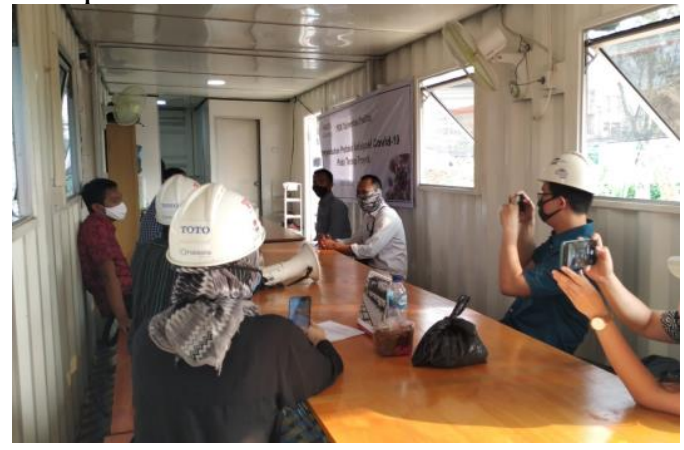

Gambar 4. Dokumentasi Koordinasi dengan

Pelaksana Proyek di Kawasan Symphonia

Summarecon Serpong disesuaikan dengan physical distancing dan pengkondisian ventilasi udara 
Pre-test digunakan untuk mengukur tingkat pemahaman pekerja tentang COVID-19 adalah sehingga kegiatan sosialisasi dapat tepat sasaran disesuaikan dengan pemahaman pekerja konstruksi. Bahan untuk pre-test dibagi menjadi 2 (dua), yaitu :1) tingkat pengetahuan pekerja konstruksi terhadap pandemi Covid-19 dikhususkan pada perilaku pencegahan Covi-19 secara individu, dan 2) pengetahuan terhadap protokol kesehatan yang diterapkan pada pekerja konstruksi sesuai dengan rencana protokol kesehatan dari PT.Summarecon Agung,Tbk yang merujuk pada kebijakan pemerintah di era New Normal.

Checklist secara garis besar terdiri atas 8 (delapan) pertanyaan yang disiapkan oleh pelaksana kegiatan sebagai berikut,

Tabel 1. Kisi-kisi pertanyaan pre-test

\begin{tabular}{|c|c|c|}
\hline No. & & Pertanyaan \\
\hline 1 & $\begin{array}{l}\text { Pengetahuan } \\
\text { umum } \\
\text { tentang } \\
\text { COVID-19 }\end{array}$ & $\begin{array}{l}\text { 1) Apakah Anda tahu cara } \\
\text { transmisi virus atau } \\
\text { penularan COVID-19? } \\
\text { 2) Apakah Anda tahu dampak } \\
\text { COVID-19 terhadap tubuh? } \\
\text { 3) Apa Anda mengenal istilah- } \\
\text { istilah yang diberikan oleh } \\
\text { Tim Penanganan COVID- } \\
19 \text { pemerintah? }\end{array}$ \\
\hline 2 & $\begin{array}{l}\text { Pengetahuan } \\
\text { tentang } \\
\text { pencegahan } \\
\text { COVID-19 }\end{array}$ & $\begin{array}{l}\text { 4) Apakah Anda tahu cara dan } \\
\text { sudah melakukan langkah- } \\
\text { langkah dalam mencuci } \\
\text { tangan yang baik dan benar, } \\
\text { maupun mengaplikasikan } \\
\text { hand sanitizer? } \\
\text { 5) Apakah Anda tahu cara } \\
\text { memakai masker wajah } \\
\text { yang baik dan benar, serta } \\
\text { etika bersin -batuk? } \\
\text { 6) Apakah Anda tahu jarak } \\
\text { physical distancing secara } \\
\text { optimal? } \\
\text { 7) Apakah Anda menerapkan } \\
\text { pola hidup sehat? }\end{array}$ \\
\hline 3 & $\begin{array}{l}\text { Pengetahuan } \\
\text { tentang } \\
\text { berbagai } \\
\text { Protokol } \\
\text { COVID-19 }\end{array}$ & $\begin{array}{l}\text { Apakah Anda tahu tentang } \\
\text { protokol kesehatan COVID- } \\
19 ?\end{array}$ \\
\hline
\end{tabular}

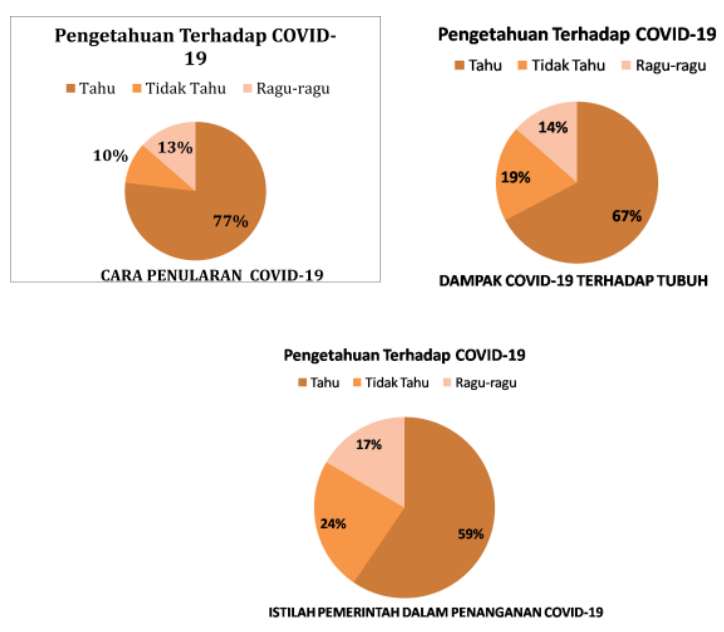

Gambar 5. Gambaran Hasil Prestest mengenai pengetahuan umum COVID-19

Dari paparan data di atas, didapatkan bahwa pekerja konstruksi sebenarnya cukup mengerti adanya kejadian pandemi Covid-19 secara umum, namun untuk cara penularan dan dampak terhadap tubuh masih terdapat jawaban pekerja yang raguragu karena kesimpang-siuran informasi di masyarakat. Dan masih ada beberapa yang memerlukan pemahaman lebih lanjut, misalnya pemahaman mengenai Orang Tanpa Gejala (OTG) menjadi salah satu hal yang perlu disoroti di dalam pelaksanaan sosialisasi karena OTG merupakan hal penting, terlebih ketika individu merasa sehat dan mengabaikan protokol kesehatan padahal terinfeksi tanpa disadari. Selain itu, terdapat kemungkinan pembaruan-pembaruan istilah dari pemerintah yang dapat disosialisasikan mendatang

\section{Pelaksanaan}

Pelaksanaan dilakukan dalam format semacam safety tool box talk untuk menyesuaikan kebiasaan pekerja proyek konstruksi sehingga diharapkan lebih dapat menyerap materi yang disampaikan. Acara berlangsung pada hari Jumat, 26 Juni 2020 dengan durasi kurang lebih 1.5 (satu setengah) jam di titik-titik proyek konstruksi yang sedang berjalan. Acara dilakukan di luar ruangan, pelaksana dan peserta kegiatan menggunakan pelindung diri sesuai dengan K3 dan Protokol Pencegahan COVID-19, serta memenuhi syarat physical distancing, yaitu 
antarpekerja berdiri dengan jarak kurang lebih 2 (dua) meter saat pelaksanaan kegiatan.

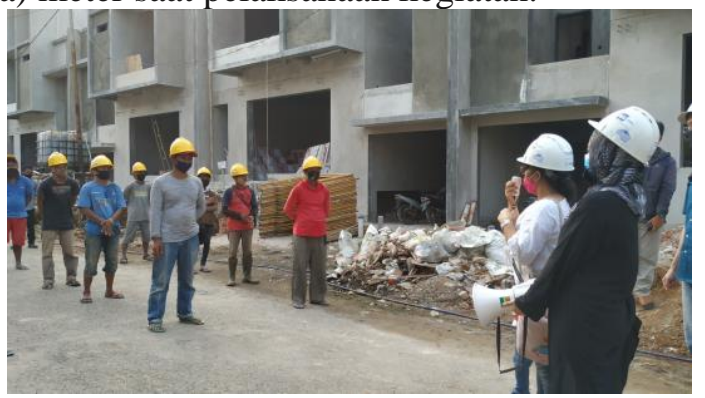

Gambar 6. Pelaksanaan Sosialisasi COVID-19 dan

Kesehatan bagi Pekerja Proyek Konstruksi di Kawasan Symphonia Gading Serpong Tangerang

Materi sosialisasi sesuai dengan pre-test yang telah diberikan, dilakukan secara lisan dengan rundown acara sebagai berikut:

Tabel 2 Rundown Pelaksanaan Acara

\begin{tabular}{lll}
\hline No. & Rundown Acara & Person In Charge \\
\hline 1 & Pembukaan & \\
2 & $\begin{array}{l}\text { Pengetahuan tentang } \\
\text { COVID-19 }\end{array}$ & Anisza Ratnasari \\
3 & $\begin{array}{l}\text { Demonstrasi } \\
\text { Pemberian desain poster } \\
\text { di lokasi proyek }\end{array}$ & Imaniar Sofia \\
5 & Penutup & Bersama- sama \\
\hline
\end{tabular}

1) pengetahuan umum tetang COVID-19, yaitu cara virus menginfeksi manusia khususnya penyebaran melalui droplet, dampak kesehatan yang ditimbulkan, faktor-faktor yang dapat meningkatkan risiko keparahan penyakit, serta beragam istilah penanganan wabah COVID-19 dari pemerintah yang wajib diketahui oleh masyarakat agar dapat mengikuti dan melakukan pemilahan secara kritis terhadap berita-berita yang beredar. Dilanjutkan dengan cara pencegahan penyebaran COVID-19 dengan pola hidup bersih dan sehat. Pola hidup bersih dan sehat akan membantu peningkatan imunitas pekerja proyek agar terhindar dari COVID-19 maupun penyakit infeksius lainnya. Pemaparan Skema kerja protokol pencegahan penyebaran Covid-19 dalam penyelenggaraan jasa konstruksi juga diberikan agar pekerja konstruksi selalu menaati protokol. Pelaksana kegiatan, Anisza Ratnasari menjadi PIC dalam memberikan pengarahan hal ini.
2) Pengetahuan tentang pencegahan COVID-19 melalui presentasi lisan dan peragaan atau demonstrasi yang dapat dilakukan individu pekerja proyek atau self assesment : pencatatan atau tracking kontak dengan orang lain, kesadaran untuk melakukan karantina mandiri dan melaporkan ke pihak yang berwenang apabila melakukan kegiatan berisiko, cara mencuci tangan dengan sabun dan hand sanitizer dengan baik, cara pemakaian masker medis-non medis, physical distancing, dan menerapkan etika batuk dan bersin di lokasi proyek konstruksi.

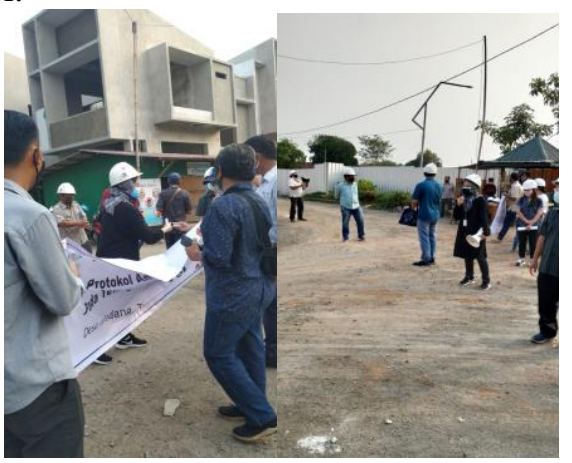

Gambar 7. Pemberian hand sanitizer untuk dilakukan praktik pemakaian bersama-sama

Pemberian hand sanitizer dari pelaksana kegiatan kepada pekerja konstruksi untuk dipraktikkan cuci tangan dengan hand sanitizer bersama-sama, dan dilakukan mengkoreksi jika ada pemakaian yang kurang tepat. Pengecekan pemakaian masker di pekerja konstruksi dilakukan untuk memastikan pekerja konstruksi sudah mempraktikkan secara baik dan benar. Penanggung jawab pelaksanaan kegiatan ini adalah Imaniar Sofia. Pengertian dan koreksi diberikan kepada para pekerja konstruksi yang belum memakai alat pelindung diri secara optimal.

- Peragaan / demonstrasi protokol penerimaan Menjelaskan tatacara registrasi atau pendataan pekerja proyek untuk pengecekan tingkat risiko - Peragaan/ demonstrasi protokol pelaksanaan; Menjelaskan tatacara desinfektanisasi tubuh dan alas kaki dan tatacara pengecekan suhu di lapangan oleh petugas 


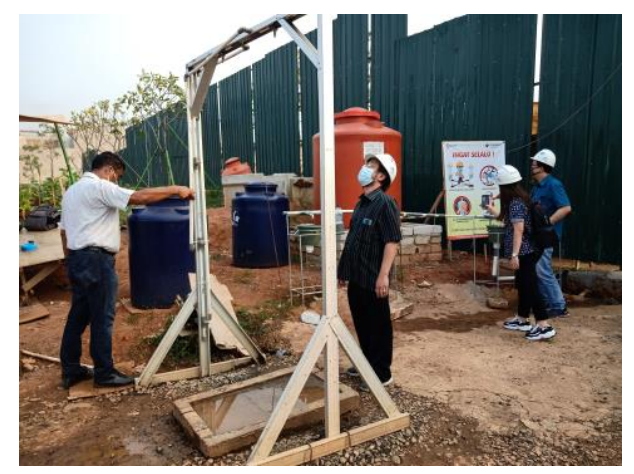

Gambar 5. Demonstrasi pekerja konstruksi harus melewati proses desinfektanisasi tubuh dan alas kaki

Selain dilakukan secara oral, terdapat media cetak untuk membantu visualisasi pelaksanaan sosialisasi, dan dipasang di titik tempat cuci tangan. Desain poster disusun oleh Marchelia Gupita. Desain poster diusahakan secara eksplisit, desain sederhana, dengan kata-kata pendek sederhana agar mudah agar mudah dimengerti.

1) Desain poster mengenai pemakaian masker yang baik dan benar untuk menghindari kesalahan-kesalahan umum dalam pemakaian masker yang berdampak pada berkurangnya efektivitas pencegahan transmisi virus COVID-19.

2) Desain poster tentang tata cara mencuci tangan memakai sabun maupun hand sanitizer secara baik benar

3) Desain poster tentang physical distancing yang baik dan benar di lokasi proyek, tidak berkerumun, tidak saling meminjamkan peralatan pribadi tanpa mencuci tangan terlebih dulu

4) Desain poster tentang pola hidup sehat dan makanan bergizi yang dapat meningkatkan imunitas bagi pekerja konstruksi
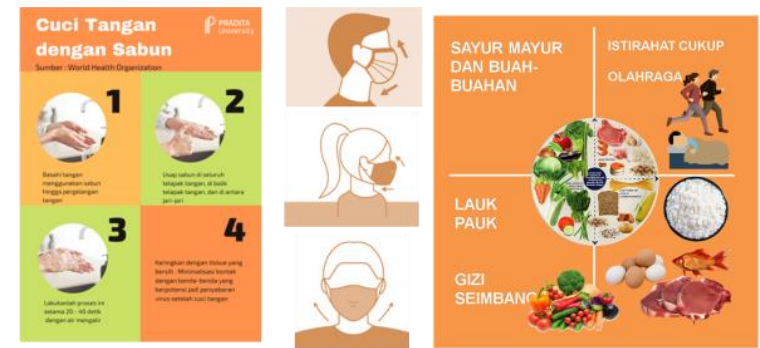

Gambar 8. Konten desain poster yang menjadi alat bantu sosialisasi

\section{Evaluasi}

Secara umum, antusiasme pekerja konstruksi dalam pelaksanaan kegiatan Pengabdian kepada Masyarakat cukup tinggi, terbukti dari tingkat partisipasi individu pekerja proyek di dalam proses pelaksanaan kegiatan dari awal hingga akhir. Peserta menyimak penjelasan dari pelaksana an mengajukan pertanyaan jika ada penjelasan yang kurang jelas. Pekerja konstruksi nampak berusaha mematuhi protokol yang telah diterima.

Sebagai tindak lanjut dari pre-test, pelaksana mengadakan post-test untuk para pekerja dengan teknik pengumpulan data wawancara secara mengingat kesibukan proyek. Post-test menggunakan kisi-kisi pertanyaan pada pre-test yang dibagi menjadi 3 (tiga) poin, yakni 1) Pengetahuan umum COVID-18, 2) Pencegahan COVID-19, dan 3) Protokol Kesehatan COVID-19. Dapat terlihat bahwa terdapat penambahan tingkat pemahaman pekerja konstruksi mengenai Covid-19 dengan adanya kegiatan sosialisasi ini. Berdasarkan hasil wawancara, sebagian besar pekerja proyek mengalami peningkatan terhadap pengetahuan penularan COVID-19, dampak COVID-19 terhadap tubuh manusia, maupun pengetahuan terhadap istilah-istilah penanganan COVID-19 oleh pemerintah.

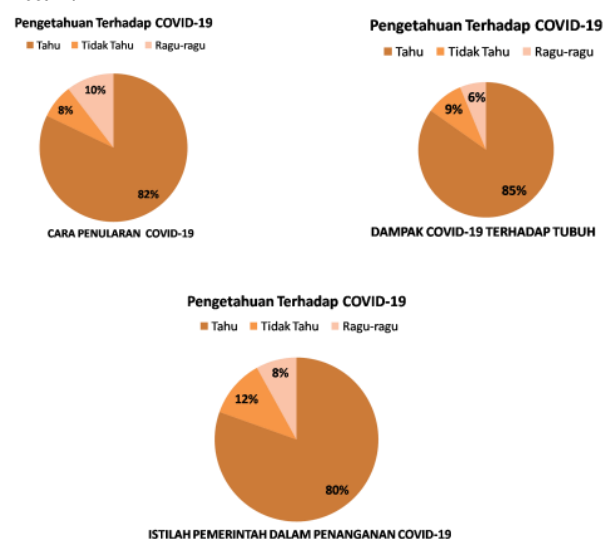

\section{Gambar 9. Peningkatan pengetahuan pekerja konstruksi terhadap COVID-19}

Dalam poin kedua post-test tentang Pencegahan COVID-19, para pekerja konstruksi telah dapat menyebutkan langkah-langkah cuci tangan dengan sabun secara baik dan benar sekaligus dapat memperagakannya, dapat memperagakan memakai 
masker pelindung dengan baik, dan menyebutkan dan mempraktikkan etika batuk dan bersin. Pekerja proyek mengetahui pola hidup sehat dan makanan sehat yang baik untuk imunitas tubuh dari konten poster.

Pengetahuan pencegahan COVID-19 secara umum sudah diketahui dan dapat dipraktikan langsung langsung mengikuti demonstrasi pelaksana di lapangan, namun diperlukan pengawasan dalam pelaksanaannya untuk melihat konsistensi pekerja proyek melaksanakan protokol kesehatan. Maka dari itu, pada poin ketiga mengenai protokol kesehatan COVID-19 perlu perlu dilakukan kegiatan tersendiri tentang pengawasan secara berkala. Diharapkan kegiatan pengawasan dapat menjadi usulan kegiatan selanjutnya.

\section{KESIMPULAN}

Serangkaian kegiatan Peningkatan Kesehatan pada Manajemen Proyek saat Pandemi berupa Sosialisasi kepada pekerja proyek sudah dilakukan dengan lancar atas dukungan dari berbagai pihak yang terlibat. Namun begitu, kegiatan ini tentunya masih jauh dari sempurna dan masih perlu untuk dilakukan pengembangan dan masukan yang membangun dalam kegiatan selanjutnya atau kegiatan mendatang.

Kegiatan ini merupakan kegiatan yang sangat diperlukan untuk pekerja konstruksi di mana proyek pembangunan fisik tidak dapat serta merta ditinggalkan atau diberhentikan walau hanya sementara waktu karena melibatkan banyak pertimbangan. Untuk itu, perlu dilakukan pada lokasi proyek lain dengan perlibatan pihak akademisi dan praktisi.

Agar pelaksanaan berjalan lebih lancar, untuk pre-test dan post-test dapat dilakukan lebih terstruktur agar mendapatkan gambaran yang lebih jelas. Peragaan atau demonstrasi dengan format acara safety tool box talk merupakan cara yang efektif untuk penyampaian materi sosialisasi di lokasi proyek konstruksi.

\section{UCAPAN TERIMAKASIH}

Ucapan terima kasih kami tujukan untuk Gugus Tugas Covid-19, Summarecon Serpong, khususnya untuk pelaksana proyek kawasan Symponia atas waktu dan kesediaannya bersama-sama melaksanakan kegiatan ini. Selain itu, ucapan terima kasih juga kami tujukan untuk Lembaga Penelitian dan Pengabdian Masyarakat (LPPM) Universitas Pradita yang mendanai pelaksanaan PkM ini.

\section{REFERENSI}

Instruksi Menteri Pekerjaan Umum dan Perumahan Rakyat (PUPR) Nomor C2/1N/M/2020 tentang Protokol Pencegahan Covid-19 Dalam Penyelenggaraan Jasa Konstruksi.

Keputusan Menteri Kesehatan Republik Indonesia Nomor: HK01.07/Menkes/249/2020.

https://covid19.go.id/p/protokol/kemen-puprprotokol-pencegahan-covid-19-di-proyek-

konstruksi

https://covid19.kemkes.go.id/protokol-covid19/protokol-pencegahan-covid-19-di-proyekkonstruksi/\#.XwU7-ygzbIU 